\title{
Mathematical models of delaying opening of SIDI injectors formulated on basis of optical tests
}

\begin{abstract}
An appropriate moment of the fuel injection start is one of the parameters determining the characteristics of fuel flow from the injector and preparation of fuel-air mixture for combustion. However, knowledge of the characteristics of signals controlling the beginning of the injector opening does not provide enough information about the time of the actual fuel injection, which often leads to incorrect conclusions and decisions in relation to the required changes in the map of injection control.

What was undertaken in this research was an attempt to evaluate the delay times of the actual opening of the highpressure injectors of gasoline in relation to the time of triggering the current control signals opening the solenoid and piezoelectric injectors. The conducted tests take into account the variability of fuel injection pressure and backpressure prevailing in the operational chamber of the engine. To accurately determine the time of actual start of injection, the optical tests analysing the optical image of the tip of the dispenser were used. Such high resolution images were obtained thanks to high-speed filming with a frequency of $250 \mathrm{kHz}(\Delta t=0.004 \mathrm{~ms})$. Correlation of the results of these analyses with the records of parameters of the fast-varying processes (voltage and current in the injector) allowed determining the times of the electric and hydraulic delay of the injection for piezoelectric and solenoid fuel injectors. Based on a comparison of the results obtained, it was found that the delay time of fuel injection for a piezoelectric injector of gasoline is about 3.5 times shorter than for a solenoid injector. It was also found that for the injection pressure above 10 MPa the delay is constant and does not depend on the pressure of fuel and the medium.

Experimentally obtained results of the injection time delay were a basis to formulate mathematical models describing the delay of the actual fuel injection in relation to the signal controlling the opening of the injectors. These models take into account the dependence of the injector reaction on the injection pressure and the backpressure in the operational chamber of the engine. The correctness of the obtained models is confirmed by high values of the coefficient of determination (above 0.84).
\end{abstract}

Key words: direct fuel injection, injection delay, piezoelectric injectors, solenoid injectors, optical tests

\section{Modele matematyczne opóźnienia otwarcia wtryskiwaczy SIDI sformułowane na podstawie badań optycznych}

\begin{abstract}
Odpowiednia chwila początku wtrysku paliwa jest jednym z parametrów decydujących o przebiegu wypływu paliwa z wtryskiwacza oraz o przegotowaniu mieszanki paliwowo-powietrznej do spalania. Jednak znajomość przebiegu sygnałów sterujących początkiem otwarcia wtryskiwacza nie dostarcza wystarczajacych informacji o chwili rzeczywistego wtrysku paliwa, co często staje się przyczyną błędnych wniosków i decyzji w odniesieniu do wymaganych zmian w mapie sterowania wtryskiem.

W tej pracy podjęto próbę oceny czasów opóźnienia rzeczywistego otwierania wtryskiwaczy wysokociśnieniowych benzyny w stosunku do czasów wyzwolenia prąowych sygnałów sterujących otwarciem wtryskiwaczy elektromagnetycznych i piezoelektrycznych. W przeprowadzonych badaniach uwzględniono zmienność ciśnienia wtrysku paliwa oraz przeciwciśnienia panujacego w komorze roboczej silnika. Do dokładnego określenia chwili rzeczywistego początku wtrysku wykorzystano badania optyczne polegające na analizie obrazu końcówki rozpylacza. Obrazy takie o dużej rozdzielczości uzyskano dzięki szybkiemu filmowaniu z częstotliwościa $250 \mathrm{kHz}(\Delta t=0,004 \mathrm{~ms})$. Skorelowanie wyników tych analiz z wynikami rejestracji parametrów procesów szybkozmiennych (napięcia i natężenia prądu we wtryskiwaczu) pozwoliło na wyznaczenie czasów opóźnienia elektrycznego i hydraulicznego wtrysku paliwa dla wtryskiwaczy piezo- i elektromagnetycznych. Na podstawie porównania uzyskanych wyników stwierdzono, że czas opóźnienia wtrysku paliwa dla wtryskiwaczy piezoelektrycznych benzyny jest około 3,5-krotnie krótszy niż dla wtryskiwaczy elektromagnetycznych. Stwierdzono także, że powyżej ciśnienia wtrysku $10 \mathrm{MPa}$ opóźnienie to jest stałe i nie zależy od wartości ciśnienia paliwa i ośrodka. Eksperymentalnie uzyskane wyniki opóźnienia czasu wtrysku stanowity podstawę do sformułowania modeli matematycznych opisujących opóźnienie rzeczywistego wtrysku paliwa w stosunku do sygnatu sterującego otwarciem wtryskiwaczy. Modele te uwzględniaja zależność reakcji wtryskiwacza od ciśnienia wtrysku oraz przeciwciśnienia w przestrzeni roboczej silnika. O poprawności otrzymanych modeli świadcza duże wartości współczynnika determinacji (powyżej 0,84).
\end{abstract}

Słowa kluczowe: bezpośredni wtrysk paliwa, opóźnienie wtrysku, wtryskiwacze piezoelektryczne, wtryskiwacze elektromagnetyczne, badania optyczne

\section{Introduction}

To ensure proper combustion process in engines with direct gasoline injection, a vitally important parameter is the moment of supplying a relevant portion of fuel into the

\section{Introduction}

Do zapewnienie właściwego przebiegu procesu spalania w silnikach z bezpośrednim wtryskiem benzyny niezmiernie istotna jest chwila dostarczenia odpowiednich porcji paliwa 
combustion space. It should be remembered that the moment of sending an electrical signal to the actuator of the injector is not the same at the moment of actual opening of the injector.

Injection systems in gasoline engines are quite diverse. The engines with multipoint indirect injection of gasoline into the inlet valve (MPI - Multi Point Injection) use a low-pressure solenoid injectors supplied with the on-board network voltage of the vehicle. Due to an external fuel mixing, the speed of operation of such injectors is not a critical parameter.

More and more common nowadays, direct gasoline injection requires the use of the high-pressure solenoid or piezoelectric injectors, where the speed and precision of operation is much higher. The speed of their operation influences the time of the start of fuel injection into the combustion chamber, and from the delay in the reaction to the signal controlling the injector opening depends, to a large extent, the precision of fuel dosing and maintaining appropriate dosing strategy. The delay in the actual opening of the injector in relation to the signal controlling injector opening is an important issue in terms of the course of combustion process (in particular its dynamics) close to the TDC of the piston. This issue gained particular importance due to dynamic development of the engines with direct gasoline injection, as well as due to the instructions to create stratified mixtures using multiple injection during a single operating cycle.

The issue of the delays of the actual start of fuel injection in modern injectors controlled electromagnetically and piezoelectrically, depending on the injection pressure and the backpressure in the operating space of the engine, as well as the issue of modelling the delays are subjects of this study.

\section{Earlier studies and investigations}

In the so-called conventional fuel injectors, opening of the needle of the atomiser is caused by acting of the hydraulic pressure, generated by the fuel supplied to the atomiser and produced by the fuel pump, on the surface of the needle cone. Lifting of the needle over the socket takes place when the so-called injection opening pressure is exceeded, producing a force that overcomes the preload of the spring pressing the needle against the socket. In such injection systems the start of the injection is usually identified on the basis of the course of pressure changes before the injector (taking into account the delay in recording of pressure changes arising from the distance of the pressure sensor from the sac of the injector) or on the basis of the direct measurement of the needle movement, which, however, requires extension of the needle and the use of additional, high-precision measuring system.

In contemporary fuel injectors these methods, however, are not useful because of the battery (common rail) type of power supply, very slight needle stroke and the fact that it's impossible to extend the needle, and also because of the very high frequency and speed of the needle motion. For these reasons, only a few research teams have tried to assess the actual movement of the needle in the injector, and the tests undertaken led to rather indirect conclusions. In addition, needle motion is no longer forced only by the hydraulic do przestrzeni spalania. Trzeba przy tym pamiętać, że chwila wysłania elektrycznego sygnału sterującego do elementu wykonawczego wtryskiwacza nie jest tożsama z chwilą jego rzeczywistego otwarcia.

Układy wtryskowe silników benzynowych są dosyć zróżnicowane. W silnikach wyposażonych w wielopunktowy wtrysk pośredni benzyny na zawór dolotowy (MPI - Multi Point Injection) wykorzystuje się niskociśnieniowe wtryskiwacze elektromagnetyczne zasilane napięciem sieci pokładowej pojazdu. Ze względu na zewnętrzny sposób tworzenia mieszanki palnej szybkość działania takich wtryskiwaczy nie jest wielkością krytyczną.

Coraz powszechniej stosowany współcześnie bezpośredni wtrysk benzyny wymaga użycia wysokociśnieniowych wtryskiwaczy elektromagnetycznych lub piezoelektrycznych, których szybkość i precyzja działania jest dużo lepsza niż wtryskiwaczy niskociśnieniowych. Od szybkości ich działania zależy czas rozpoczęcia wtrysku paliwa do komory spalania, a od opóźnienia reakcji na sygnał sterujący otwarciem wtryskiwacza zależy w dużym stopniu precyzja dawkowania paliwa oraz zachowania odpowiedniej strategii jego podawania. Opóźnienie rzeczywistego otwarcia wtryskiwacza w stosunku do sygnału sterującego otwarciem jest zagadnieniem istotnym $\mathrm{w}$ aspekcie przebiegu procesu spalania (szczególnie jego dynamiki) w okolicy GMP tłoka. Zagadnienie to zyskało duże znaczenie w związku z dynamicznym rozwojem silników z bezpośrednim wtryskiem benzyny, a także ze względu na zalecenia tworzenia mieszanki uwarstwionej przez stosowanie wtrysku wielokrotnego w czasie jednego cyklu roboczego.

Zagadnienia rzeczywistego opóźnienia procesu początku wtrysku benzyny we współczesnych wtryskiwaczach sterowanych elektromagnetycznie i piezoelektrycznie, w zależności od ciśnienia wtrysku oraz przeciwciśnienia w przestrzeni roboczej silnika, jak również zagadnienia modelowania tego opóźnienia stanowią przedmiot tego opracowania.

\section{Weześniejsze prace i badania}

W tak zwanych klasycznych wtryskiwaczach paliwa otwarcie iglicy rozpylacza następuje w wyniku działania na powierzchnię stożka iglicy siły naporu hydraulicznego, wywołanego ciśnieniem paliwa dostarczanego do rozpylacza, a wytwarzanym przez ciśnieniową pompę paliwową. Uniesienie się iglicy ponad gniazdo następuje z chwilą przekroczenia tzw. ciśnienia otwarcia wtryskiwacza, wytwarzającego siłę powodującą pokonanie napięcia wstępnego sprężyny dociskającej iglicę do gniazda. W takich układach wtryskowych początek wtrysku identyfikuje się zwykle na podstawie przebiegu zmian ciśnienia przed wtryskiwaczem (z uwzględnieniem opóźnienia rejestracji zmian ciśnienia wynikającego z oddalenia czujnika ciśnienia od studzienki wtryskiwacza) lub przez bezpośredni pomiar ruchu iglicy, co jednak wymaga przedłużenia samej iglicy i zastosowania dodatkowego, precyzyjnego układu pomiarowego.

We współczesnych silnikowych wtryskiwaczach paliwa metody te są jednak mało przydatne ze względu na zasilanie typu akumulatorowego (zasobnikowego), bardzo nieznaczny skok iglicy oraz brak możliwości jej przedłużenia, a także 
pressure of the fuel, but also by the opening of the solenoid or piezoelectric injector controlled by the electric signal sent from the system controlling fuel injection. The system is so complex and difficult to test, that measurements of the delay of fuel injection have been undertaken so far by relatively few research teams. Below are discussed only selected, most important publications.

Zhang et al. [10] analysing various sequences of opening direct solenoid injectors determined the delay of their opening (in relation to the occurrence of an opening signal) at about $0.4 \mathrm{~ms}$, regardless of the value of fuel pressure, which ranged from 2 to $20 \mathrm{MPa}$.

Similar studies using solenoid injectors supplied with the voltage of 40-70 V DC were conducted by Tsai and Yu [9] in relation to the motorcycle engine with a cylinder capacity of $500 \mathrm{~cm}^{3}$. In these studies, an analysis of the course of electrical signals of the inward-opening type of injector was conducted, and the value of the injector delay was determined. It was found that the delay of opening of highpressure solenoid gasoline injectors achieved approximately $0.33 \mathrm{~ms}$ (for $\mathrm{P}_{\text {inj }}=10 \mathrm{MPa}, \mathrm{t}_{\text {inj }}=1.5 \mathrm{~ms}$ ).

In experimental and simulation tests of the solenoid injectors carried out by Cheng et al. [2] an injector of SIDI engine was used controlled by the voltage of $70 \mathrm{~V}$. For the analysis of injector operation different strategies of controlling the voltage supply were used. It was concluded that, despite the fact that the time of the initial voltage impulse was as high as $0.39 \mathrm{~ms}$, the amperage obtained the value of about $1.5 \mathrm{~A}$, insufficient to start the lift of the injector needle. Increasing the time of the triggering the needle by the value of $0.3 \mathrm{~ms}(0.69 \mathrm{~ms})$ at high current (max. value of $19 \mathrm{~A}$ ) allowed to cause the movement of the needle. The delay of the start of the needle movement amounted then to $0.1 \mathrm{~ms}$. It also proved that the lift of the needle starts at the current value of about $4 \mathrm{~A}$.

In these studies, the measurements for the needle lift were conducted with the use of laser methods. Unfortunately, this technique did not allow filling the injector with fuel. This means that time obtained is the time of only electric delay, without taking into account the hydraulic delay. In fact, during the flow of fuel to the nozzle sac, this time may be different due to acting of forces generated by fuel pressure.

Currently known are the publications concerning the analysis of the delay of solenoid gasoline [9] and diesel injectors [eg. 3, 5]. There is, however, no detailed analysis for piezoelectric injectors of gasoline - although these injectors have been more and more often used for several years in combustion engines with direct injection of gasoline. Only few publications undertake this issue. Sim et al. [6] presenting numeric analysis of fuel atomisation for piezoelectric injector adopted the injection time delay of $0.1 \mathrm{~ms}$, taking into account the additional opening $(0.05 \mathrm{~ms})$ and closing $(0.07 \mathrm{~ms})$ time of the injector. In the cited publication there is, however, no discussion concerning the tests, on the basis of which these values were determined.

\section{The research problem}

Earlier publications of the authors of this paper [7, 8] focused on quantitative analysis of gasoline injection delay, ze względu na bardzo duże częstotliwości i szybkości jej ruchu. $Z$ tych względów tylko nieliczne zespoły badawcze mogą ocenić rzeczywisty ruch iglicy we wtryskiwaczu, a podejmowane badania mają raczej charakter wnioskowania pośredniego. Ponadto wymuszenie ruchu iglicy nie wynika już wyłącznie z naporu hydraulicznego paliwa, lecz z otwarcia siłownika elektromagnetycznego lub piezoelektrycznego sterowanego sygnałem prądowym, pochodzącym z układu sterującego wtryskiem paliwa. Układ taki jest więc złożony i trudny badawczo, co powoduje, że pomiarami opóźnienia wtrysku paliwa zajmowały się dotychczas nieliczne zespoły badawcze. Poniżej omówiono jedynie ich wybrane najważniejsze prace.

Zhang i in. [10], analizując różne sekwencje otwarcia wtryskiwaczy elektromagnetycznych bezpośredniego działania, określili opóźnienie ich otwarcia (w odniesieniu do pojawienia się sygnału otwierającego) na około $0,4 \mathrm{~ms}$, niezależnie od wartości ciśnienia paliwa, które zawierało się w przedziale 2-20 $\mathrm{MPa}$.

Podobne badania z wykorzystaniem wtryskiwaczy elektromagnetycznych zasilanych napięciem 40-70 V DC prowadzili Tsai i Yu [9] w odniesieniu do silnika motocyklowego o pojemności skokowej $500 \mathrm{~cm}^{3}$. W badaniach tych przeprowadzono analizę przebiegu sygnałów elektrycznych wtryskiwacza typu inward-opening i określono wartość opóźnienia jego działania. Stwierdzono, że opóźnienie otwarcia wysokociśnieniowych elektromagnetycznych wtryskiwaczy benzyny wynosi około $0,33 \mathrm{~ms}$ (przy nastawach $P_{\text {inj }}=10 \mathrm{MPa}, \mathrm{t}_{\text {inj }}=1,5 \mathrm{~ms}$ ).

W symulacyjnych i eksperymentalnych badaniach wtryskiwaczy elektromagnetycznych prowadzonych przez Cheng $\mathrm{i}$ in. [2] wykorzystano wtryskiwacz silnika SIDI sterowany napięciem 70 V. Do analizy działania wtryskiwacza wykorzystano różne strategie zasilania napięcia sterującego. Jak stwierdzono, mimo że czas wstępnego impulsu napięciowego wynosił aż $0,39 \mathrm{~ms}$, to natężenie prądu osiągało wartość około 1,5 A, niewystarczającą do rozpoczęcia wzniosu iglicy wtryskiwacza. Zwiększenie czasu wyzwolenia o wartość $0,3 \mathrm{~ms}$ (do 0,69 ms) przy dużej wartości prądu (o maks. wartości 19 A) pozwoliło na wywołanie ruchu iglicy. Opóźnienie chwili rozpoczęcia ruchu iglicy wynosiło wówczas $0,1 \mathrm{~ms}$. Wykazano także, że wznios iglicy rozpoczyna się przy wartości natężenia prądu około $4 \mathrm{~A}$.

W badaniach tych pomiar wzniosu iglicy dokonano metodami laserowymi. Niestety, zastosowanie takiej techniki nie pozwoliło na wypełnienie wtryskiwacza paliwem. Oznacza to, że uzyskany czas jest czasem opóźnienia elektrycznego, bez uwzględnienia opóźnienia hydraulicznego. W rzeczywistości, przy napływie paliwa do studzienki rozpylacza, czas ten może być inny ze względu na działanie sił wywołanych ciśnieniem paliwa.

Obecnie znane są prace dotyczące analiz opóźnienia wtrysku dla wtryskiwaczy elektromagnetycznych benzyny [9] i oleju napędowego [np. 3, 5]. Brak jest jednak szczegółowych analiz dotyczących wtryskiwaczy piezoelektrycznych benzyny, mimo że wtryskiwacze takie stosowane są coraz powszechniej od kilku lat w silnikach spalinowych 
without taking into account the mathematical methods allowing the description of functional dependencies. In the tests it was proved that the hydraulic delay $\left(\mathrm{t}_{\mathrm{h}}\right)$ of the piezoelectric gasoline injectors amounts to about $90 \mu \mathrm{s}$, which is $95 \%$ of the total delay $\left(\mathrm{t}_{\mathrm{d}}\right.$ ) of fuel injection (for fuel pressure of $5 \mathrm{MPa})$ The remaining time $(5 \%)$ applies to the so-called electric delay $\left(\mathrm{t}_{\mathrm{e}}\right)$, that is, the time between occurrence of the signal controlling injection and the start of the increase of voltage in the injector cylinder. With increasing pressure of fuel this delay decreases. For fuel injection pressure of $20 \mathrm{MPa}$ it is only about $85 \%$ of the delay occurring at low fuel pressure.

The publications discussed in this paper aimed at the elemental analysis of the impact of characteristic parameters on the process of fuel injection delay (fuel pressure and backpressure). On the basis of the results of experimental studies was developed the mathematical description of the fuel injection delay relating to high-pressure solenoid and piezoelectric gasoline injectors.

\section{Research methodology}

The tests of fuel injection delay were conducted for piezoelectric (Tab. 1) and solenoid injectors (Tab. 2). Test injectors were placed in a constant volume chamber (Fig. 1 ), and the fuel injection delay was filmed using highspeed cameras (Tab. 3), with the recording frequency of $250 \mathrm{kHz}$. For this frequency the subsequent images are recorded every $4 \mu \mathrm{s}$.

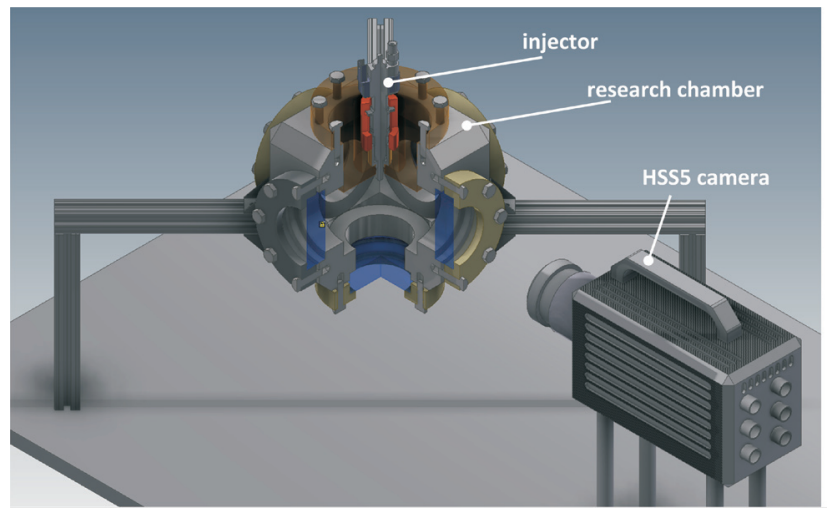

Fig. 1. The test bench for optical tests of the delay of fuel injection Rys. 1. Schemat stanowiska badawczego do badań optycznych opóźnienia wtrysku paliwa z bezpośrednim wtryskiem benzyny. Pojawiają się jedynie pojedyncze prace dotyczące tego zagadnienia. Sim i in. [6], prezentując numeryczną analizę rozpylenia paliwa z wtryskiwacza piezoelektrycznego, przyjęli czas opóźnienia wtrysku na $0,1 \mathrm{~ms}$, w którym uwzględniono dodatkowy czas otwarcia wtryskiwacza $(0,05 \mathrm{~ms})$ oraz jego zamknięcia $(0,07 \mathrm{~ms})$. W przytoczonej pracy brak jest jednak omówienia badań, na podstawie których te wartości określono.

\section{Problem badawczy}

Wcześniejsze prace autorów tego opracowania $[7,8]$ dotyczyły analiz ilościowych opóźnienia wtrysku benzyny, bez uwzględnienie aparatu matematycznego, pozwalającego na opis zależności funkcyjnych. W badaniach tych wykazano, że opóźnienie hydrauliczne $\left(\mathrm{t}_{\mathrm{h}}\right)$ wtryskiwaczy piezoelektrycznych benzyny wynosi około $90 \mu$ s, co stanowi $95 \%$ całkowitego opóźnienia $\left(\mathrm{t}_{\mathrm{d}}\right)$ wtrysku paliwa (przy ciśnieniu paliwa o wartości $5 \mathrm{MPa}$ ). Pozostały czas (5\%) dotyczy opóźnienia tzw. elektrycznego $\left(\mathrm{t}_{\mathrm{e}}\right)$, czyli czasu pomiędzy pojawieniem się sygnału sterującego wtryskiem a początkiem narastania napięcia w siłowniku wtryskiwacza. Wraz ze zwiększaniem ciśnienia paliwa opóźnienie to ulega zmniejszeniu. Przy ciśnieniu wtrysku paliwa 20 MPa wynosi już tylko około 85\% opóźnienia występującego przy małej wartości ciśnienia paliwa.

Celem omawianych tutaj prac jest analiza pierwiastkowa wpływu charakterystycznych wielkości na proces opóźnienia wtrysku paliwa (ciśnienia paliwa oraz przeciwciśnienia powietrza). Na podstawie wyników badań eksperymentalnych opracowano matematyczny opis opóźnienia wtrysku paliwa odnoszący się do wysokociśnieniowych elektromagnetycznych i piezoelektrycznych wtryskiwaczy benzyny.

\section{Metodyka badawcza}

Badania opóźnienia wtrysku paliwa przeprowadzono dla wtryskiwaczy piezoelektrycznych (tab. 1) i elektromagnetycznych (tab. 2). Badane wtryskiwacze umieszczano w komorze stałej objętości (rys. 1), a opóźnienie wtrysku paliwa filmowano z użyciem kamery do szybkiego filmowania (tab. 3), z częstotliwością rejestracji $250 \mathrm{kHz}$. Przy takiej częstotliwości kolejne obrazy rejestrowane są co $4 \mu \mathrm{s}$.

Dla obu typów wtryskiwaczy badania prowadzono przy odmiennych wartościach czasów wtrysku: krótsze czasy wtrysku stosowano przy badaniach wtryskiwaczy piezoelektrycznych, a dłuższe - przy elektromagnetycznych. Przyjęte czasy otwarcia

Table 1. Piezoelectric fuel injector specification [4]

Tabela 1. Charakterystyka wtryskwiacza piezoelektrycznego [4]

\begin{tabular}{|l|c|}
\hline Injector & Outward-opening piezo-injector \\
\hline Dynamic flow & $14.5 \mathrm{mg} / \mathrm{inj} \pm 10 \%$ at $0.4 \mathrm{~ms}$ \\
\hline Minimum dynamic flow & $<2 \mathrm{mg} / \mathrm{str}$ \\
\hline Spray angle & $90^{\circ} \pm 3^{\circ}$ \\
\hline SMD size & $\sim 15 \mu \mathrm{m}$ \\
\hline Opening/closing time & $>150 \mu \mathrm{s}$ \\
\hline Maximum voltage & $190 \mathrm{~V}$ \\
\hline System pressure & $5-20 \mathrm{MPa}$ \\
\hline
\end{tabular}


Table 2. Technical specification of solenoid injector [1]

Tabela 2. Charakterystyka wtryskwiacza elektromagnetycznego [1]

\begin{tabular}{|l|c|}
\hline Parameter & Value \\
\hline Flow rate & $<22.5 \mathrm{~cm}^{3} / \mathrm{s}$ at $10 \mathrm{MPa}$ \\
\hline Leakage & $<2.5 \mathrm{~mm}^{3} / \mathrm{min}$ at $10 \mathrm{MPa}$ \\
\hline SMD size & $15 \mu \mathrm{m}$ \\
\hline System pressure & $<20 \mathrm{MPa}$ \\
\hline
\end{tabular}

For both types of injectors the test were conducted for different values of the injection times: shorter injection times were used for the piezoelectric injectors, and longer times - for the solenoid injectors. The adopted injector opening times were derived from typical values used in combustion engines, when fuel dose division is applied. In the tests were applied four values of the fuel pressure and four values of backpressure of air, into which the fuel was injected. The test was repeated three times. The conditions of tests of fuel injection delay are presented in Table 4. The adopted, diversified minimum opening times for piezo- and solenoid injectors ( 0.2 and $0.3 \mathrm{~ms}$ ) ensue from technical capabilities of their operation.

Table 4. Conditions of tests of fuel injection

Tabela 4. Warunki prowadzenia badań wtrysku paliwa

\begin{tabular}{|l|c|l|}
\hline Energizing time $[\mathrm{ms}]$ & \multirow{2}{*}{$\mathrm{t}_{\text {inj }}$} & piezoinjector: $0.2 ; 0.4 ; 0.6$ \\
\cline { 3 - 3 } & & solenoid: $0.3 ; 0.5 ; 0.7$ \\
\hline Fuel injection pressure $[\mathrm{MPa}]$ & $\mathrm{P}_{\text {inj }}$ & $5 ; 10 ; 15 ; 20$ \\
\hline Air back-pressure $[\mathrm{MPa}]$ & $\mathrm{P}_{\mathrm{b}}$ & $1.5 ; 2.0 ; 2.5 ; 3.0$ \\
\hline Temperature $[\operatorname{deg} \mathrm{C}]$ & $\mathrm{T}$ & $293 \mathrm{~K}$ \\
\hline
\end{tabular}

In the test were used IndiModule system for acquisition of fast-varying signals by AVL company (recording frequency of $500 \mathrm{kHz} ; \Delta \mathrm{t}=2 \mu \mathrm{s}$ ), which enabled recording of electric characteristics in the injector (intensity and voltage) and the electrical signal of a LED diode. The flash of the light of the diodes was also recorded in the video, serving as the element synchronizing optical studies with the registered characteristics of the current (Fig. 2).

Characteristics of the current-voltage signals from injectors allowed to obtain information about the delay in the

a)

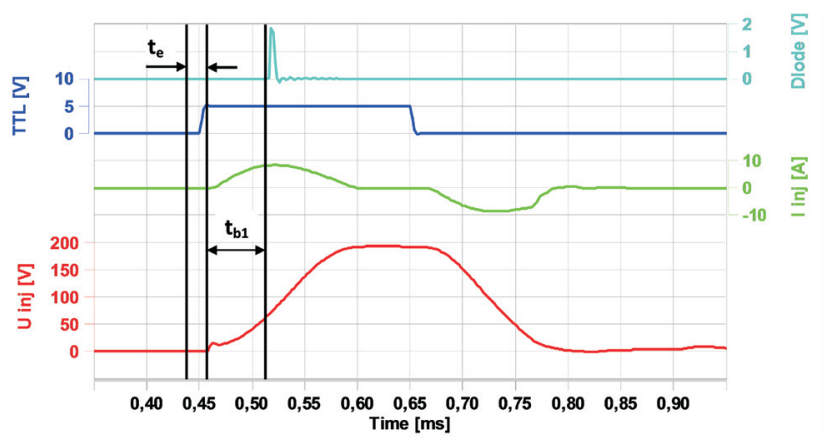

wtryskiwaczy wynikają z typowych wartości wykorzystywanych w silnikach spalinowych, gdy stosowany jest podział dawki paliwa. W badaniach zastosowano cztery wartości ciśnienia paliwa oraz cztery wartości przeciwciśnienia powietrza, do którego następował wtrysk paliwa. Badania powtarzano trzykrotnie. Warunki badań opóźnienia wtrysku paliwa przedstawiono w tabeli 4. Przyjęte, zróżnicowane minimalne czasy otwarcia wtryskiwaczy piezo- i elektromagnetycznych $(0,2$ oraz 0,3 ms) wynikają z technicznych możliwości ich działania.

Table 3. Details of the optical setup and devices employed to evaluate the fuel injection delay

Tabela 3. Charakterystyka elementów optycznych wykorzystanych w badaniach opóźnienia wtrysku paliwa

\begin{tabular}{|l|c|}
\hline Camera & LaVision HighSpeedStar 5 \\
\hline Light source & Halogen lamp $-2 \times 500 \mathrm{~W}$ \\
\hline Camera lens & Nikon Nikkor \\
\hline Lens features & $50 \mathrm{~mm}-\mathrm{f} / 1.4$ \\
\hline Image size [pix] & $71 \times 16$ \\
\hline Image size [mm] & $84.2 \mathrm{~mm} \times 86.9 \mathrm{~mm}$ \\
\hline Frame rate [fps] & 250000 \\
\hline Pixel/mm [-] & 4.4875 \\
\hline Test repetitions [-] & 3 \\
\hline
\end{tabular}

Do badań wykorzystano układ akwizycji procesów szybkozmiennych IndiModule firmy AVL (z częstotliwością rejestracji $500 \mathrm{kHz} ; \Delta \mathrm{t}=2 \mu \mathrm{s}$ ), który umożliwił rejestrację przebiegów elektrycznych we wtryskiwaczu (natężenia i napięcia prądu) oraz sygnału elektrycznego diody świecącej. Błysk światła diody zarejestrowany także na filmie pełnił funkcję elementu synchronizującego badania optyczne z zarejestrowanymi przebiegami prądowymi (rys. 2).

b)

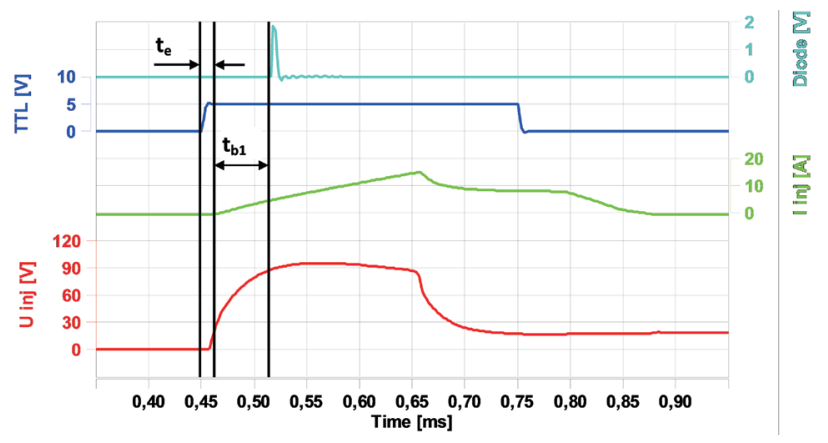

Fig. 2. The analysis of the electrical signals of the injectors: a) piezoelectric, b) solenoid Rys. 2. Analiza sygnałów elektrycznych wtryskiwaczy: a) piezoelektrycznych, b) elektromagnetycznych 
electric opening of injectors $\left(\mathrm{t}_{\mathrm{e}}\right)$ defined as the time from triggering the TTL signal until the start of the increase of amperage. In a similar way also the time elapsing between the increase in the amperage and activation of the LED diode signal was determined $\left(\mathrm{t}_{\mathrm{b} 1}\right)$. The time from the input signal activating LED diode until the flow of fuel from the injector is designated as $t_{b 2}$ and was determined on the basis of the optical tests. The sum of these times is the total hydraulic delay of an injector:

$$
\mathrm{t}_{\mathrm{h}}=\mathrm{t}_{\mathrm{b} 1}+\mathrm{t}_{\mathrm{b} 2}
$$

Synchronization of the electrical and optical test allowed to determine the total time of the delay in operation of injectors $\left(\mathrm{t}_{\mathrm{d}}\right)$, as is schematically shown in Figure 2:

$$
\mathrm{t}_{\mathrm{d}}=\mathrm{t}_{\mathrm{e}}+\mathrm{t}_{\mathrm{h}}
$$

In order to capture the start of fuel flow, the optical tests involved high-speed filming with high time and surface resolution of the area of one selected orifice of the atomizer. The first drops of fuel reflect the illuminating light and are identified as areas with increased intensity of radiation. However, in order to precisely determine the moment of appearance of the first drop, the recorded images (Fig. 3a) had to be digitally processed, which involved the following:

1) subtracting the measuring background - noise - Fig. 3b,

2) determining the time of diode flashing - Fig. 3c,

3 ) evaluation of the time of capturing the photo, in which drops of fuel flowing from injector appear - Fig. 3d.

Such processing was applied to the images of the recorded LED diode flash and injection of fuel from both types of injectors. The results of these analyses are shown in Figure 4, in which the sequence of subsequent images is presented, and the time of recording an image of fuel drops determines the time of opening solenoid and piezoelectric injector. A comparison with the time of initiation of the signal controlling the injector allows specifying the delay of its activation, which is the start of the fuel injection.

This procedure has been applied to all adopted conditions of the study, and the results obtained in this way are described in section 5 .

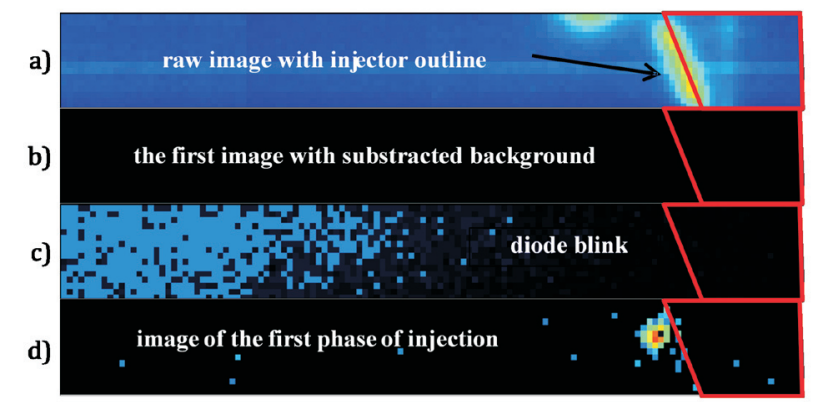

Fig. 3. Optical research algorithm of fuel injection based on data from piezoinjector: $\mathrm{ET}=0.4 \mathrm{~ms}, \mathrm{P}_{\mathrm{inj}}=20 \mathrm{MPa}, \mathrm{P}_{\mathrm{b}}=1.5 \mathrm{MPa}$

Rys. 3. Algorytm wyznaczania początku wtrysku na podstawie badań optycznych z wtryskiwacza piezoelektrycznego: $E T=0,4 \mathrm{~ms}$, $P_{i n j}=20 \mathrm{MPa}, P_{b}=1,5 \mathrm{MPa}$
Przebiegi sygnałów prądowo-napięciowych wtryskiwaczy umożliwiły uzyskanie informacji o opóźnieniu elektrycznym otwarcia wtryskiwaczy $\left(\mathrm{t}_{\mathrm{e}}\right)$, określonym jako czas od wyzwolenia sygnału TTL do pojawienia się przyrostu natężenia prądu. W podobny sposób określono również czas upływający od zwiększania natężenia prądu do wymuszenia działania diody $\left(\mathrm{t}_{\mathrm{b} 1}\right)$. Czas od wymuszenia świecenia diody do wypływu paliwa określono jako $t_{b 2} i$ wyznaczono na podstawie badań optycznych. Suma tych czasów stanowi całkowite opóźnienie hydrauliczne wtryskiwacza (1).

Synchronizacja badań elektrycznych i optycznych pozwoliła na określenie całkowitego czasu opóźnienia działania wtryskiwaczy $\left(\mathrm{t}_{\mathrm{d}}\right)$ - wzór (2), jak to schematycznie pokazano na rys. 2 .

Badania optyczne polegały na filmowaniu z dużą rozdzielczością czasową i powierzchniową obszaru jednego wybranego otworka rozpylacza w celu uchwycenia chwili początku wypływu paliwa. Pojawiające się pierwsze krople paliwa odbijają światło oświetlające i są identyfikowane jako obszary o zwiększonej intensywności promieniowania. Aby jednak w sposób precyzyjny określić chwilę pojawienia się pierwszych kropli, zarejestrowane kolejne obrazy (rys. 3a) należało poddać obróbce cyfrowej polegającej na:

1) odjęciu tła pomiarowego - szumu - rys. $3 b$,

2) określeniu czasu błysku diody - rys. 3c,

3) ocenie czasu wykonania zdjęcia, na którym pojawiają się krople paliwa z wtryskiwacza - rys. $3 \mathrm{~d}$.

Taki sposób obróbki zastosowano do obrazów zarejestrowanego błysku diody i wtrysku paliwa z obu typów wtryskiwaczy. Efekty tych analiz przedstawiono na rys. 4, na którym zawarto sekwencje kolejnych obrazów, a czas zarejestrowania obrazu z pojawiającymi się kroplami paliwa określa czasy otwarcia wtryskiwacza piezoelektrycznego i elektromagnetycznego. Porównanie z czasem powstania sygnału sterującego wtryskiwaczem pozwala na określenie opóźnienia jego działania, czyli początku wtrysku paliwa.

Takie postępowanie zastosowano dla wszystkich przyjętych warunków badań, a uzyskane w ten sposób wyniki przedstawiono w rozdz. 5.

\section{Investigation of injection delay for piezo- and solenoid injectors}

Analiza opóźnienia otwarcia wtryskiwaczy elektromagnetycznych wskazuje na istnienie zależności tego opóźnienia od wartości przeciwciśnienia panującego w komorze pomiarowej. Na podstawie danych z rys. 5 można stwierdzić, że zależność ta jest istotna przy ciśnieniu $5 \mathrm{MPa}$ : wraz ze zwiększaniem przeciwciśnienia zwiększa się opóźnienie otwarcia wtryskiwacza. Zależność ta występuje niezależnie od wartości czasu wtrysku paliwa $\left(\mathrm{t}_{\mathrm{inj}}\right)$. Przy innych, większych wartościach przeciwciśnienia zależność taka nie jest obserwowana. Analiza opóźnienia działania wtryskiwacza piezoelektrycznego wskazuje na istnienie podobnych zależności przy ciśnieniu wtrysku 5 MPa. Jednak analiza opóźnienia działania przy większych wartościach ciśnienia paliwa i przeciwciśnienia ośrodka wskazuje na występowanie (w niektórych przypadkach) również podobnej zależności (rys. 6). 


\section{Investigation of injection delay for piezo- and solenoid injectors}

Analysis of the delay of opening the solenoid injectors points to the existence of a dependency of this delay from the value of the backpressure in the measuring chamber. Based on the data from Figure 5, it can be concluded that this relationship is important at a pressure of $5 \mathrm{MPa}$ : with increasing backpressure the delay of injector opening increases. This dependency occurs regardless of the value of the fuel injection time $\left(\mathrm{t}_{\mathrm{inj}}\right)$. For other, higher values of backpressure this dependence is not observed. The analysis of the delay in activation of the piezoelectric injector indicates the existence of similar dependencies at the injection pressure of $5 \mathrm{MPa}$. However, the analysis of the delay in activation of the injector for higher values of fuel pressure and medium backpressure points to the existence (in some cases) of similar dependency (Fig. 6).

From the analysis of the data concerning delays in operation of the piezo- and solenoid injectors it might be concluded that the time of the delay in opening both types of injectors:

- does not depend on the time of injection duration - no unequivocal trend of changes was obtained;

- does not depend on the backpressure of the medium at a pressure above $5 \mathrm{MPa}$; there is no constant, unequivocal trend observed in the changes; an outline of a trend for increasing delay appears during operation of the injector at a pressure above $15 \mathrm{MPa}$; it is not, however, a dominating trend;

- it depends proportionally on the value of the backpressure of the medium at fuel injection pressure of $\mathrm{P}_{\text {inj }}=5 \mathrm{MPa}$, but at higher pressures this trend is not unequivocal.

So presented conclusions indicated the necessity of additional comparison of the injection delay for each value of fuel pressure, taking into consideration the time of the injection and the backpressure of the air. The results of the analysis were complemented with characteristic parameters of the delay time of fuel flow from an injector:

a) an average value:

$$
\mathbf{x}_{\mathrm{av}}=\frac{\sum_{\mathrm{i}=1}^{\mathrm{n}} \mathrm{x}_{\mathrm{i}}}{\mathrm{n}}
$$

b) medium: the value of the parameter in ordered series, below and above which identical number of observations exists (for even number of elements - arithmetic mean of the two middle values),

c) dominant: a value with the highest probability of occurrence.
Z analizy ogólnych danych dotyczących opóźnienia działania wtryskiwaczy piezo- i elektromagnetycznych można wnioskować, że opóźnienie czasu otwarcia wtryskiwaczy obu typów:

- nie zależy od czasu trwania wtrysku - nie uzyskano jednoznacznej tendencji zmian,

- nie zależy od przeciwciśnienia ośrodka przy ciśnieniu powyżej $5 \mathrm{MPa}$; brak jest stałej, jednoznacznej tendencji zmian; zarys tendencji zwiększającego się opóźnienia pojawia się podczas pracy wtryskiwaczy przy ciśnieniu wtrysku powyżej $15 \mathrm{MPa}$, jednak nie jest to trend dominujący,

- zależy proporcjonalnie od wartości przeciwciśnienia ośrodka przy ciśnieniu wtrysku paliwa o wartości $\mathrm{P}_{\text {inj }}=$ $=5 \mathrm{MPa}$, jednak przy ciśnieniach większych tendencja ta nie jest jednoznaczna.

Tak sformułowane wnioski wskazały na konieczność dodatkowego zestawienia opóźnienia wtrysku przy każdej wartości ciśnienia paliwa z uwzględnieniem czasu wtrysku i przeciwciśnienia powietrza. Wyniki tych działań uzupełniono o wyznaczenie charakterystycznych wielkości opóźnienia czasu wypływu paliwa z wtryskiwacza:

a) wartości średniej

$$
x_{a v}=\frac{\sum_{i=1}^{n} x_{i}}{n}
$$

b) mediany: wartość cechy w szeregu uporządkowanym, powyżej i poniżej której znajduje się jednakowa liczba obserwacji (przy parzystej liczbie elementów - średnia arytmetyczna dwóch środkowych liczb), 

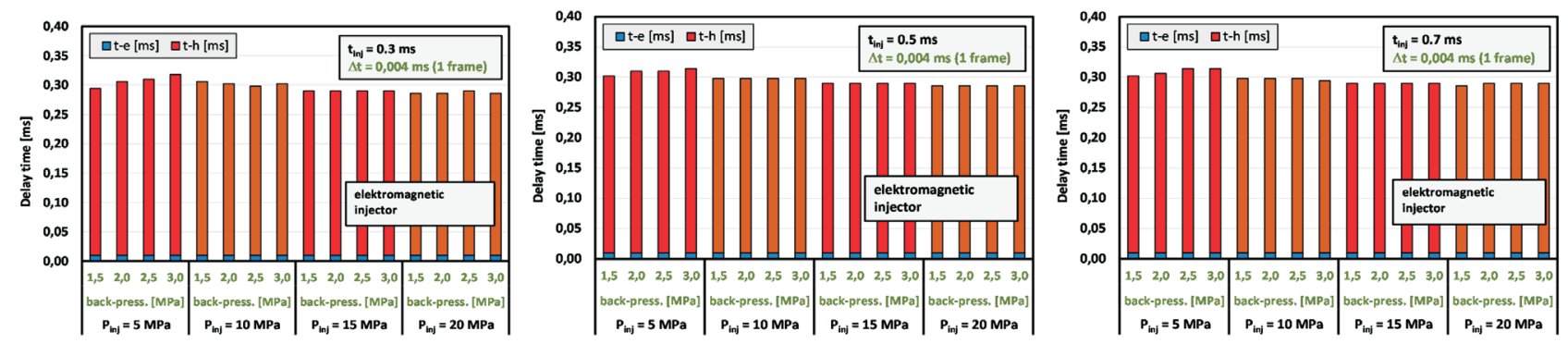

Fig. 5. Analysis of the times of injection delay at variable pressure of fuel injection and backpressure of air during operation of a solenoid injector Rys. 5. Analiza czasów opóźnienia wtrysku przy zmiennym ciśnieniu wtrysku paliwa oraz przeciwciśnieniu powietrza podczas pracy wtryskiwacza elektromagnetycznego
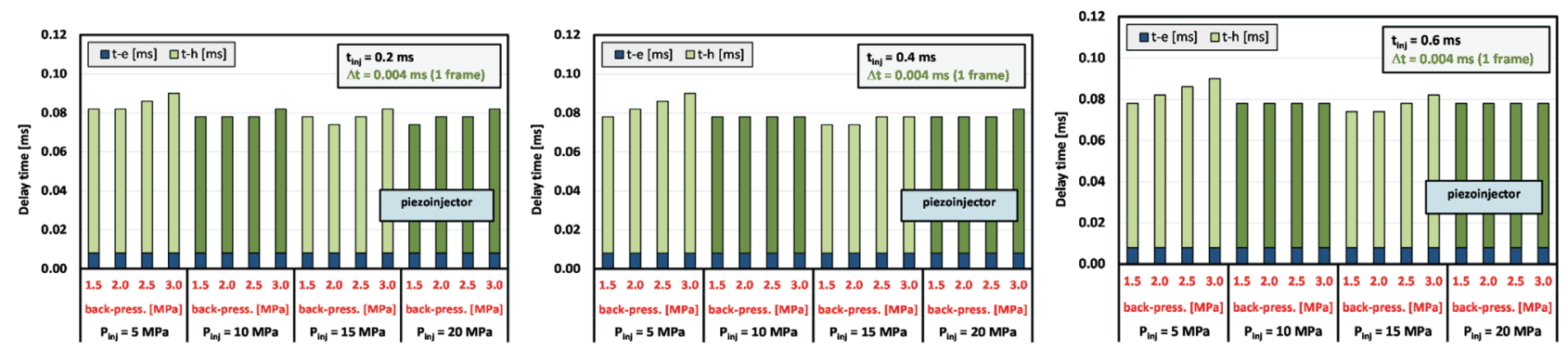

Fig. 6. Analysis of the times of injection delay at variable pressure of fuel injection and backpressure of air during operation of a piezoelectric injector Rys. 6. Analiza czasów opóźnienia wtrysku przy zmiennym ciśnieniu wtrysku paliwa oraz przeciwciśnieniu powietrza podczas pracy wtryskiwacza piezoelektrycznego

So determined parameters of the delay of fuel flow from an injector are presented in Fig. 7 (for solenoid injectors) and in Fig. 8 (for piezoelectric injector). The analysis of the trends of these parameters of delay while increasing the fuel pressure is clear: with increasing fuel pressure, the delay decreases. However, the backpressure of the medium affects these changes in a variety of ways.

The dependency of fuel flow delay from fuel pressure is stronger for solenoid injector than for piezoelectric injector. In tests of the delay of fuel flow from a piezoelectric injector no trends of changes of this delay for increasing fuel pressure were observed (Fig. 8b-d). At a pressure of $15 \mathrm{MPa}$, the values of the fuel flow delay were the lowest and amounted to approximately $75 \mu \mathrm{s}$.

The presented research results show that there are the conditions to determine mathematical dependencies concerning the time of the delay of fuel flow from the injector from the fuel injection pressure and the backpressure prevailing in the workspace. An attempt of formulating such a description is provided in section 6 .

\section{An attempt to describe in mathematical terms the delays in the start of fuel injection}

\subsection{The impact of the fuel pressure on the delay of injection}

Using the above average values, median, and a dominant of the injection time delay for individual values of injected fuel pressure (regardless of the injection time and backpressure) an attempt to formulate mathematical models was made. These models are presented in the form of a linear, c) dominanty: wartość o największym prawdopodobieństwie wystąpienia.

Tak wyznaczone cechy opóźnienia wypływu paliwa z wtryskiwacza przedstawiono na rys. 7 (dla wtryskiwacza elektromagnetycznego) oraz na rys. 8 (dla wtryskiwacza piezoelektrycznego). Analiza tendencji tych cech opóźnienia podczas zwiększania ciśnienia paliwa jest jednoznaczna: następuje zmniejszenie opóźnienia wraz ze zwiększaniem ciśnienia paliwa. Jednakże przeciwciśnienie ośrodka w różny sposób wpływa na te zmiany.

Zależność opóźnienia wypływu paliwa z wtryskiwacza od ciśnienia paliwa jest większa dla wtryskiwacza elektromagnetycznego niż dla wtryskiwacza piezoelektrycznego. W badaniach opóźnienia wypływu z wtryskiwacza piezoelektrycznego nie zaobserwowano tendencji zmian tego opóźnienia przy zwiększaniu ciśnienia paliwa (rys. 8b-d). Przy ciśnieniu 15 MPa wartości opóźnienia wypływu były najmniejsze i wynosiły około $75 \mu$ s.

Przedstawione wyniki badań wykazały, że istnieją przesłanki do wyznaczenia matematycznych zależności dotyczących czasu opóźnienia wypływu paliwa z wtryskiwaczy od ciśnienia wtrysku paliwa oraz od przeciwciśnienia w przestrzeni roboczej. Próbę takiego opisu przedstawiono w rozdz. 6.

\section{Próba opisu matematycznego opóźnienia początku wtrysku paliwa}

\subsection{Wpływ ciśnienia paliwa na opóźnienie wtrysku}

Wykorzystując przedstawione powyżej wartości średnie, medianę oraz dominantę czasu opóźnienia wtrysku dla po- 

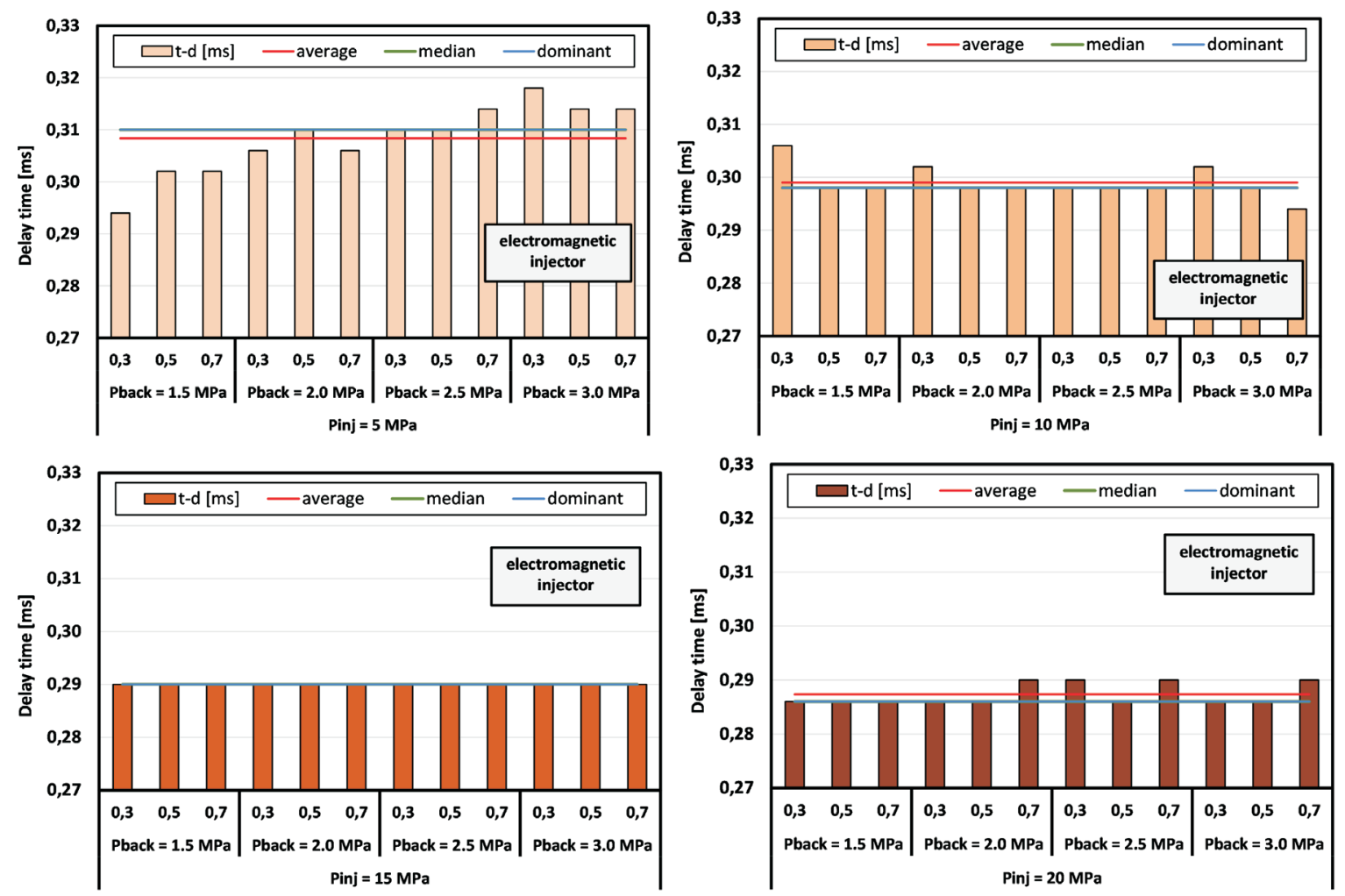

Fig. 7. Comparison of the times of fuel injection delays for solenoid injectors for four different values of fuel injection pressure $(5,10,15,20 \mathrm{MPa})$ at variable backpressure of air and different times of injection

Rys. 7. Porównanie czasów opóźnienia wtrysku paliwa z wtryskiwacza elektromagnetycznego dla czterech różnych wartości ciśnienia wtrysku paliwa $(5,10,15,20 \mathrm{MPa})$ przy zróżnicowanym przeciwciśnieniu i różnych czasach wtrysku

polynomial and exponential dependencies (Fig. 9, 10). The analysis of the obtained equations for appropriate functional dependencies indicates that they are much better correlated to the experimental results when using polynomial and exponential equations. The obtained maximum value of the coefficient of determination for models formulated for the solenoid injectors amount to 0.999 (based on the median). The degree of correlation of the exponential model is higher for each characteristic parameter (due to the higher value of the coefficient of determination). A mathematical model of the analysed dependencies, presented in linear form, seems to be useless because of the low value of the $\mathrm{R}^{2}$.

The analysis of the models of fuel injection delay formulated for piezoelectric injectors (Fig. 10) points to some slight dependency of the delay time on the value of fuel pressure. This dependency occurs only at low values of fuel injection pressure (in the range 5-10 MPa), while at higher pressure values this delay is constant. At fuel pressure of $10 \mathrm{MPa}$ and more, the delay of the fuel injection is $0.078 \mathrm{~ms}$ (regardless of which characteristic parameter it concerns - Fig. 10a-c).

It indicates that, despite application of mathematical models to describe the injection delay, their use is not reliable. The coefficients of determination for these models are low, which is due to the specificity of the obtained results concerning delays in opening the injectors. Despite the fact, that for the mean value of the injection delay and for the polynomial model the value $\mathrm{R}^{2}$ exceeds 0.99 - Fig. 10a, this szczególnych wartości ciśnienia wtryskiwanego paliwa (niezależnie od czasu wtrysku i przeciwciśnienia), podjęto próbę sformułowania odpowiednich modeli matematycznych. Modele te przedstawiono w postaci zależności liniowej, wielomianowej oraz wykładniczej (rys. 9 i 10). Analiza uzyskanych równań dla odpowiednich zależności funkcyjnych wskazuje na znacznie lepsze ich dopasowanie do wyników eksperymentalnych przy wykorzystaniu równań wielomianowych i wykładniczych. Uzyskana maksymalna wartość współczynnika determinacji modeli sformułowanych dla wtryskiwaczy elektromagnetycznych wynosi 0,999 (bazując na medianie). Stopień dopasowania modelu wykładniczego jest większy dla każdej z wielkości charakterystycznych (ze względu na większą wartość współczynnika determinacji). Model matematyczny analizowanych zależności przedstawiony w postaci liniowej wydaje się nieprzydatny ze względu na małą wartość $\mathrm{R}^{2}$.

Analiza modeli opóźnienia wtrysku paliwa sformułowanych dla wtryskiwaczy piezoelektrycznych (rys. 10) wskazuje na niewielką zależność czasu opóźnienia od wartości ciśnienia paliwa. Zależność ta występuje jedynie przy małych wartościach ciśnienia wtrysku paliwa (w zakresie 5-10 MPa), natomiast przy większych wartościach ciśnienia opóźnienie to jest stałe. Przy ciśnieniu paliwa $10 \mathrm{MPa}$ i więcej opóźnienie wtrysku wynosi 0,078 ms (niezależnie od tego, jakiej wielkości charakterystycznej dotyczy - rys. $10 \mathrm{a}-\mathrm{c})$. 

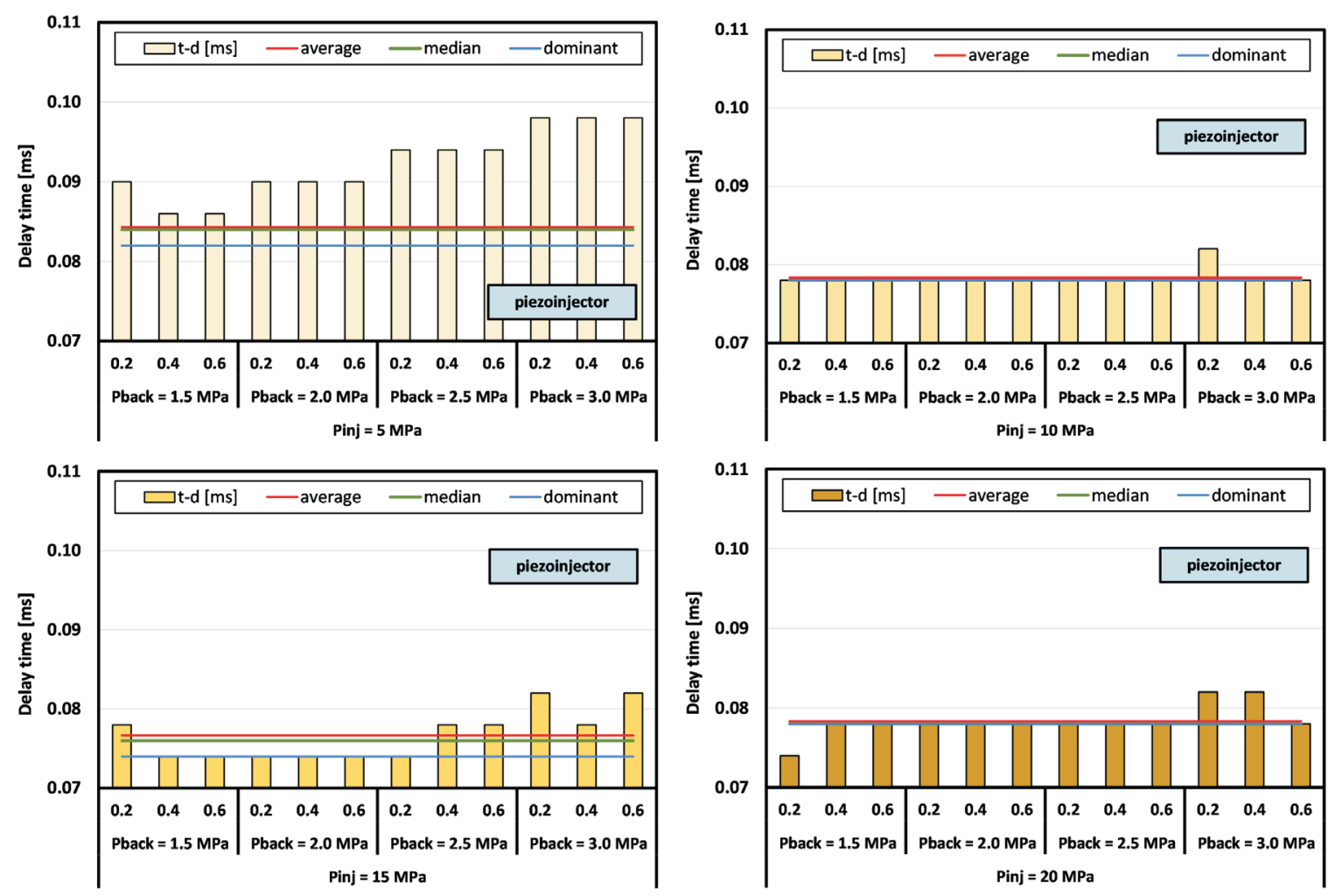

Fig. 8. Comparison of the times of fuel injection delays for piezoelectric injectors for four different values of fuel injection pressure $(5,10,15$, $20 \mathrm{MPa}$ ) at variable backpressure

Rys. 8. Porównanie czasów opóźnienia wtrysku paliwa z wtryskiwacza piezoelektrycznego dla czterech różych wartości ciśnienia wtrysku paliwa $(5,10,15,20 \mathrm{MPa})$ przy zróżnicowanym przeciwciśnieniu

equation cannot be applied to the assessment of delay due to lack of clear trends of the changes.

From the above mathematical considerations it ensues that for fuel injection pressure of $10 \mathrm{MPa}$ and more, the delay of fuel flow from the injector is constants and amounts to $0.078 \mathrm{~ms}$ and that it is independent of any other parameter.

\subsection{The impact of the backpressure of the medium on the injection delay}

Due to the observed greater sensitivity of the fuel injection delay to the value of the backpressure at low fuel pressure $\mathrm{P}_{\text {inj }}=5 \mathrm{MPa}$, the dependencies within this range were further analysed. For the injection pressure and for both types of injectors were defined mean changes in the fuel flow delay time during changing the backpressure in increments of $0.5 \mathrm{MPa}$ (Fig. 11). It was found that the value determined for calculations shall be the arithmetic mean of the three points (three times of injector opening) at a given fuel pressure and backpressure of the medium.

In the conducted analysis it was found, that the delay in opening the solenoid injectors increased by $5.3 \mu \mathrm{s}$ at increasing the backpressure in increments of $0.5 \mathrm{MPa}$. For piezo-injectors this time amounted to $3.5 \mu \mathrm{s}$, which means the piezoelectric injectors have the delay lower by 33\% for every $0.5 \mathrm{MPa}$ of the backpressure value. Due to high values of the coefficient of determination obtained, these values were adopted as representative for the whole tested population.
Wynika z tego, że pomimo zastosowania modeli matematycznych do opisu opóźnienia wtrysku, ich wykorzystanie nie jest miarodajne. Współczynniki determinacji tych modeli są małe, co wynika ze specyfiki uzyskanych wyników dotyczących opóźnienia otwarcia wtryskiwaczy. Mimo że dla wartości średniej czasu opóźnienia wtrysku i modelu wielomianowego wartość $\mathrm{R}^{2}$ wynosi powyżej 0,99-rys. 10a, to równanie nie może być zastosowane do oceny opóźnienia ze względu na brak jednoznacznej tendencji zmian.

Z przedstawionych wyżej rozważań matematycznych wynika, że przy ciśnieniu wtrysku paliwa o wartości $10 \mathrm{MPa}$ i więcej opóźnienie wypływu paliwa z wtryskiwacza jest stałe i wynosi $0,078 \mathrm{~ms}$ oraz że nie zależy ono od żadnych innych wielkości.

\subsection{Wpływ przeciwciśnienia ośrodka na opóźnienie wtrysku}

Ze względu na zaobserwowaną większą wrażliwość opóźnienia wtrysku paliwa na wartości przeciwciśnienia przy małej wartości ciśnienia paliwa $\mathrm{P}_{\text {inj }}=5 \mathrm{MPa}$, dalszej analizie poddano zależności w tym zakresie. Dla tego ciśnienia wtrysku oraz dla obu typów wtryskiwaczy określono średnie zmiany czasu opóźnienia wypływu paliwa przy zmianie przeciwciśnienia ośrodka co 0,5 $\mathrm{MPa}$ (rys. 11). Ustalono przy tym, że wartość wyznaczona do obliczeń jest średnią arytmetyczną z trzech punktów (trzech czasów otwarcia wtryskiwacza) przy danym ciśnieniu paliwa i przeciwciśnieniu ośrodka.

W przeprowadzonej analizie stwierdzono, że opóźnienie otwarcia wtryskiwaczy elektromagnetycznych zwiększa się 


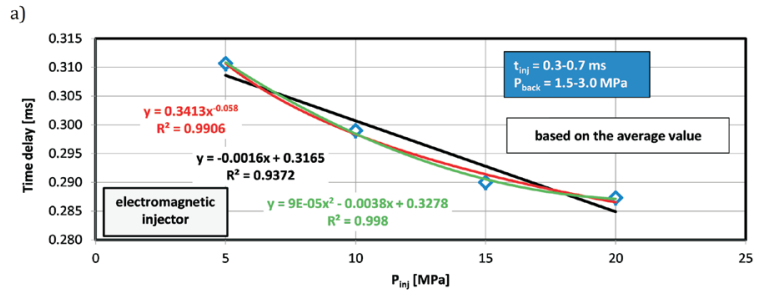

b)
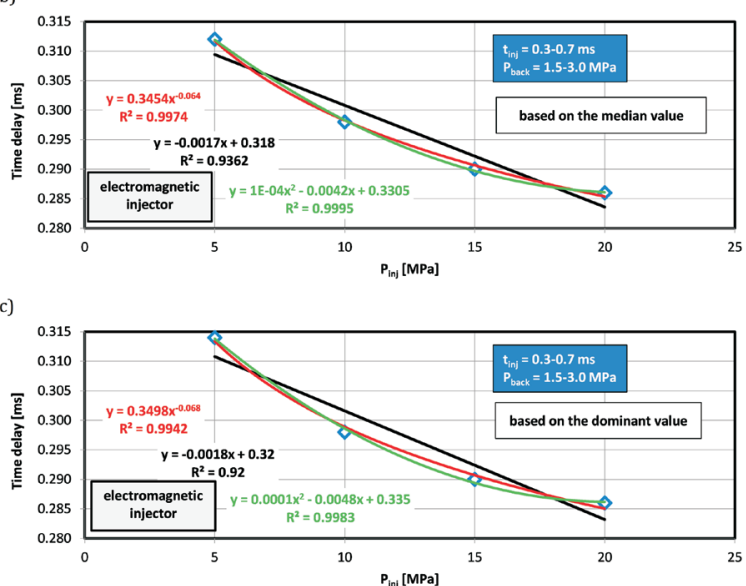

Fig. 9. Determination of mathematical models for the flow delay of solenoid injectors based on: a) mean values, b) values of the median, c) values of dominant, assuming independence of delay time from the time of the injection and backpressure; exponential model, power model, linear model

Rys. 9. Określenie matematycznych postaci modeli opóźnienia wyplywu paliwa dla wtryskiwaczy elektromagnetycznych bazujace na: a) wartościach średnich, b) wartościach median, c) wartościach dominant, przy założeniu niezależności czasu opóźnienia od czasu wtrysku i przeciwciśnienia; model wykładniczy, model potegowy, model liniowy

\subsection{A mathematical formula of the dependency of fuel injection delay}

Based on the dependencies referred to in section 6.2, an attempted was made to identify the character of the functional dependency of the fuel flow injection delay on the value of medium backpressure at low values of fuel injection pressure.

For both types of injectors one type of equation was adopted, taking into account the value of backpressure of the medium (at a constant fuel pressure $\mathrm{P}_{\text {inj }}=5 \mathrm{MPa}$ ) supplemented with the following coefficients: slope of line "a" and exponent "b". The general equation is proposed in the form of:

$$
\mathrm{t}_{\mathrm{d}(\mathrm{Pinj}=5 \mathrm{MPa})}=\mathrm{a} \cdot \mathrm{P}_{\mathrm{b}}^{\mathrm{b}}
$$

Determination of ' $a$ ' and ' $b$ ' coefficients requires the use of optimization methods. The optimisation criteria are presented in the form of a decision to be minimized $f(U)$, expressed as the sum of squares of differences of the individual values of delays of fuel flow dependent only on the backpressure of air, designated experimentally and based on equation (3).

A mathematical model contains the decision variables, constraints, and decision-making function:
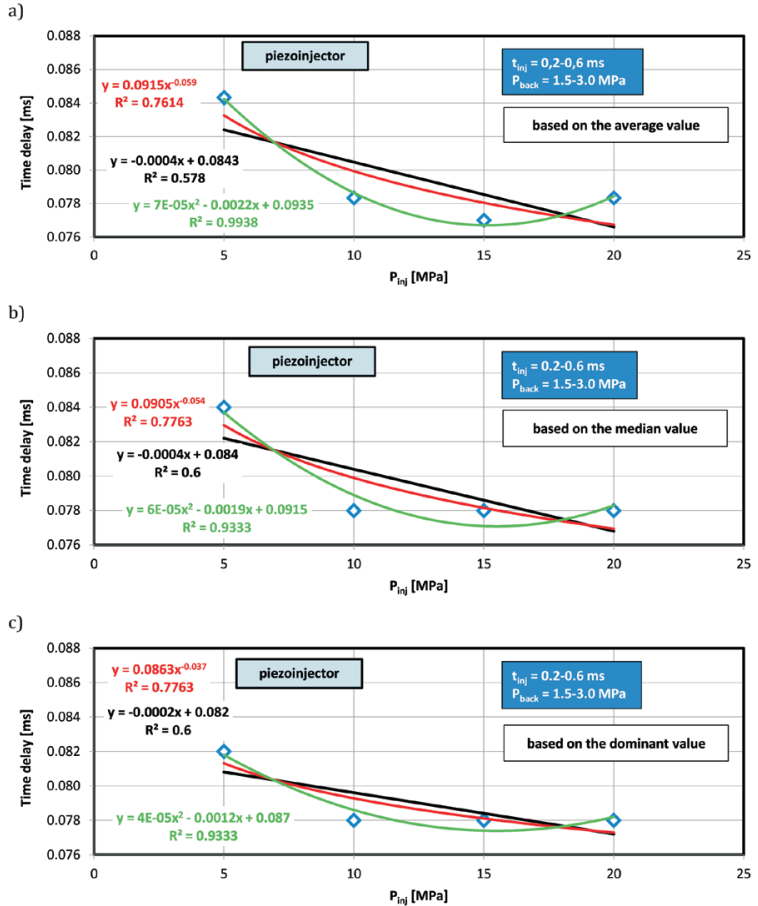

Fig. 10. Determination of mathematical models for the flow delay of piezoelectric injectors based on: a) mean values, b) values of the median, c) values of dominant, assuming independence of delay time from the time of the injection and backpressure; exponential model, power model linear model

Rys. 10. Określenie matematycznych postaci opóźnienia wypływu paliwa dla wtryskiwaczy piezoelektrycznych bazujace na: a) wartościach średnich, b) wartościach median, c) wartościach dominant, przy założeniu niezależności czasu opóźnienia od czasu wtrysku i przeciwciśnienia;

model wyktadniczy, model potęgowy, model liniowy

o 5,3 $\mu$ s przy zwiększaniu przeciwciśnienia o 0,5 MPa. Dla wtryskiwaczy piezoelektrycznych czas ten wyniósł 3,5 $\mu \mathrm{s}$, co oznacza, że wtryskiwacze piezoelektryczne mają mniejsze opóźnienie o $33 \%$ na każde $0,5 \mathrm{MPa}$ wartości przeciwciśnienia ośrodka. Ze względu na uzyskanie dużej wartości współczynnika determinacji, przyjęto te wartości za reprezentatywne dla całej badanej populacji.

\subsection{Matematyczna postać zależności opóźnienia wtrysku paliwa}

Na podstawie zależności określonych w podrozdz. 6.2 podjęto próbę określenia postaci zależności funkcyjnej opóźnienia wtrysku paliwa od wartości przeciwciśnienia ośrodka, przy małych wartościach ciśnienia wtrysku paliwa.

Dla obu typów wtryskiwaczy przyjęto jeden typ równania, uwzględniający wartość przeciwciśnienia ośrodka (przy stałej wartości ciśnienia paliwa $\mathrm{P}_{\text {inj }}=5 \mathrm{MPa}$ ), uzupełniony o współczynniki: kierunkowy „a” oraz wykładnik potęgowy „b”. Ogólne równanie zaproponowano w postaci (3).

Wyznaczenie współczynników a oraz b wymaga zastosowania metod optymalizacyjnych. Kryterium optymalności przedstawiono w postaci podlegającej minimalizacji funkcji decyzyjnej $\mathrm{f}(\mathrm{U})$, wyrażonej jako suma kwadratów różnic poszczególnych wartości opóźnienia wypływu zależnych jedynie od przeciwciśnienia powietrza, wyznaczonych doświadczalnie i na podstawie równania (3). 

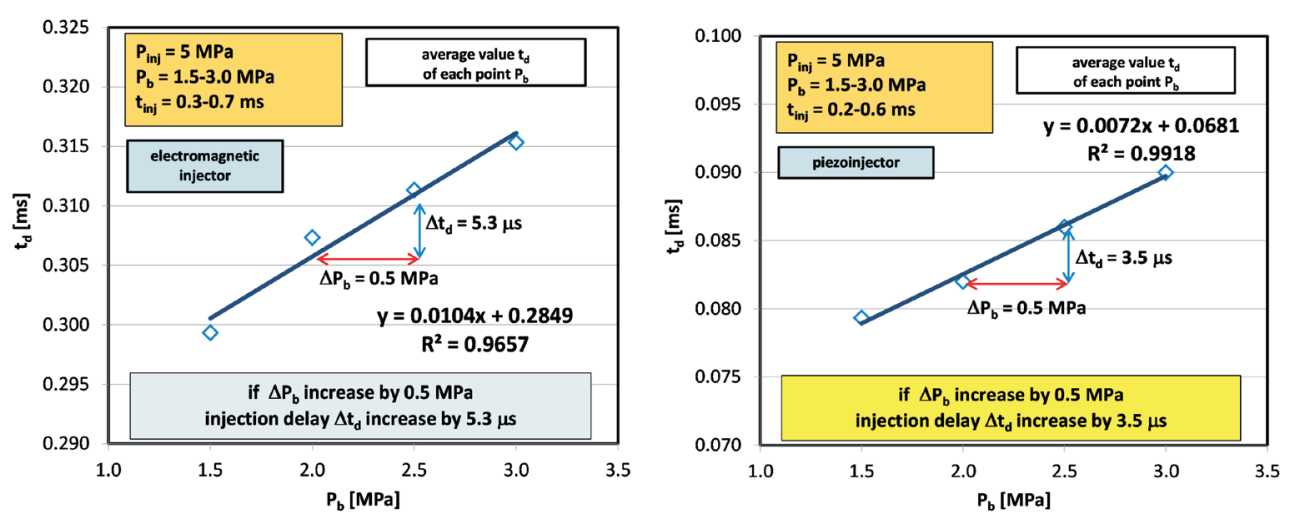

Model matematyczny zawiera zmienne decyzyjne, ograniczenia i funkcję decyzyjną:

- zmienne decyzyjne: a, b - współczynniki równania (3),

- warunek ograniczający (wyznaczający zakres rozwiązań dopuszczalnych) $\mathrm{t}_{1}: \mathrm{a}, \mathrm{b} \neq 0$, mogą to być wartości ujemne i dodatnie, z wyłączeniem zera (wartość taka eliminuje wynik równania),

Fig. 11. Analysis of the fuel injection delay during changing the backpressure $\left(\mathrm{P}_{\mathrm{inj}}=5 \mathrm{MPa}\right)$ on the basis of the average values of fuel injection using injectors: a) solenoid, b) piezoelectric

Rys. 11. Analiza opóźnienia wtrysku paliwa przy zmianie przeciwciśnienia ośrodka $\left(P_{i n j}=5 \mathrm{MPa}\right)$ na podstawie średnich wartości opóźnienia wtrysku paliwa przy zastosowaniu wtryskiwaczy: a) elektromagnetycznych, b) piezoelektrycznych

- decision variables: $\mathrm{a}, \mathrm{b}$ - coefficients of the equation (3),

- constraint (designating the range of acceptable solutions) $\mathrm{t}_{1}: \mathrm{a}, \mathrm{b} \neq 0$, values can be negative and positive, excluding zero (such value eliminates the equation),

- decision-making function: $\mathrm{U}(\mathrm{a}, \mathrm{b})$ fulfils the constraint, for which the decision-making function $f(U)$ reaches a minimum:

$$
\mathrm{f}(\mathrm{U})=\sum_{\mathrm{i}=1}^{\mathrm{n}}\left(\left(\mathrm{t}_{\mathrm{d}}\right)_{\mathrm{c}_{\mathrm{i}}}-\left(\mathrm{t}_{\mathrm{d}}\right)_{\mathrm{i}}\right)^{2} \rightarrow \min
$$

where $\left(t_{d}\right)_{c}$ - is the calculated delay value for given data of the parameters $P_{b},\left(t_{d}\right)_{i}$ - means a test value of the delay for the same values of $\mathrm{P}_{\mathrm{b}} ; \mathrm{i}$ - is a subsequent value.

The task was solved using all the fuel flow delay values (data) obtained from measurements at the pressure of $\mathrm{P}_{\text {inj }}=$ $=5 \mathrm{MPa}$. To solve the optimisation task was used the generalized reduced gradient method, implemented in MS Excel package in Solver module. It is a method of solving the task of non-linear programming with non-linear constraints. The solution to the optimization task is obtaining such coefficients of the equation (4), for which the sum of squared deviations $\left(\mathrm{t}_{\mathrm{d}}\right)_{\mathrm{c}}-\left(\mathrm{t}_{\mathrm{d}}\right)_{\mathrm{i}}$ is minimal.

For so formulated a task, in the adopted ranges of variability of the data measured at a fuel pressure of $15 \mathrm{MPa}$, were obtained results with the coefficient of determination $\mathrm{R}^{2}=0.8405$ - for solenoid injectors and $\mathrm{R}^{2}=0.9207$ for piezoelectric injectors (Fig. 12). These relatively large values of the coefficient of determination make it possible to assume that the model is correct.

The presented data do not lie in a single line because of diversified, experimental time of the delay of fuel flow from injectors at variable times of injector opening (at constant, defined conditions of injection $-\mathrm{P}_{\text {inj }}, \mathrm{P}_{\mathrm{b}}$ ). Entirely repeatable delay times, independent of the injection time (ET) cause that points at constant $t_{d}$ are in the same place. This is shown in Figure 3. 12b. Because of the operation of the piezoelectric injectors, the delay times with constant $\mathrm{P}_{\text {inj }}$ and constant $\mathrm{P}_{\mathrm{b}}$ do not depend on the injection times (ET). osiąga minimum (4), gdzie $\left(\mathrm{t}_{\mathrm{d}}\right)_{\mathrm{c}}$ oznacza obliczoną wartość opóźnienia dla danych wielkości $\mathrm{P}_{\mathrm{b}},\left(\mathrm{t}_{\mathrm{d}}\right)_{\mathrm{i}}$ - badawczą wartość opóźnienia dla tych samych wartości $\mathrm{P}_{\mathrm{b}} ; \mathrm{i}-$ kolejną wartość.

Zadanie rozwiązano, wykorzystując wszystkie wartości opóźnienia wypływu paliwa (danych) uzyskane z pomiarów przy ciśnieniu $\mathrm{P}_{\text {inj }}=5 \mathrm{MPa}$. Do rozwiązania zadania optymalizacyjnego wykorzystano uogólnioną metodę gradientu zredukowanego, zaimplementowaną w pakiecie MS Excel w module Solver. Jest to metoda rozwiązywania zadania programowania nieliniowego z ograniczeniami nieliniowymi. Rozwiązaniem zadania optymalizacji jest uzyskanie takich współczynników równania (4), dla których suma kwadratów odchyleń $\left(\left(\mathrm{t}_{\mathrm{d}}\right)_{\mathrm{c}}-\left(\mathrm{t}_{\mathrm{d}}\right)_{\mathrm{i}}\right)$ jest minimalna.

Dla tak sformułowanego zadania w zakresie przyjętej zmienności danych pomiarowych przy ciśnieniu paliwa 15 MPa uzyskano rozwiązania o współczynniku determinacji $\mathrm{R}^{2}=0,8405$ - dla wtryskiwaczy elektromagnetycznych oraz $\mathrm{R}^{2}=0,9207$ dla wtryskiwaczy piezoelektrycznych (rys. 12). Te relatywnie duże wartości współczynnika determinacji pozwalają uznać postać modelu za prawidłową.

Przedstawione dane nie leżą na jednej linii, czego powodem jest zróżnicowany, eksperymentalny czas opóźnienia wypływu paliw z wtryskiwacza przy zmiennym czasie jego otwarcia (przy stałych, ustalonych warunkach wtrysku $-\mathrm{P}_{\text {inj, }}$, $\left.\mathrm{P}_{\mathrm{b}}\right)$. Całkowicie powtarzalne czasy opóźnienia, niezależne od czasu wtrysku (ET) powodowałyby, że punkty o stałych $\mathrm{t}_{\mathrm{d}}$ znajdują się w tym samym miejscu. Sytuację taką przedstawiono na rys. $12 \mathrm{~b}$. Działanie wtryskiwaczy piezoelektrycznych powoduje, że ich czasy opóźnienia przy stałym $\mathrm{P}_{\text {inj }}$ oraz stałym $\mathrm{P}_{\mathrm{b}}$ nie zależą od czasów wtrysku (ET).

Efektem analiz przedstawionych na rys. 12 jest wniosek, że większą niezależność od czasu wtrysku wykazują wtryskiwacze piezoelektryczne (znacznie większa liczba jednakowych punktów opóźnienia na rys. 12b).

$\mathrm{Z}$ analiz przedstawionych na rys. 12 wynika, że model opisujący opóźnienie wtrysku paliwa z wtryskiwaczy elektromagnetycznych przy ciśnieniu paliwa $5 \mathrm{MPa}$ jest 
Table 5. The parameters characterizing fuel injection delay for gasoline injectors: piezo- and solenoid injectors

Tabela 5. Wielkości charakteryzujące opóźnienia wtrysku wtryskiwaczy benzynowych: piezo- i elektromagnetycznych

\begin{tabular}{|l|c|c|}
\hline & Electromagnetic injector & Piezoinjector \\
\hline Maximum injection delay & $0.318 \mathrm{~ms}$ & $0.09 \mathrm{~ms}$ \\
\hline Delay ratio EM/P $(\mathrm{P} / \mathrm{EM})$ & $1(3.53)$ & $0.28(1)$ \\
\hline Increase $\Delta \mathrm{t}_{\mathrm{d}}$ if $\Delta \mathrm{P}_{\mathrm{b}}$ increase by $0.5 \mathrm{MPa}$ & $5.3 \mu \mathrm{s}$ & $3.5 \mu \mathrm{s}$ \\
\hline Equation of injection delay & $\mathrm{t}_{\mathrm{d}}=0.29 \cdot \mathrm{P}_{\mathrm{b}}^{0.0738}$ & $\mathrm{t}_{\mathrm{d}}=0.073 \cdot \mathrm{P}_{\mathrm{b}}^{0.184}$ \\
\hline (only for $\left.\mathrm{P}_{\text {inj }}=5 \mathrm{MPa}\right)$ & 0.8405 & 0.9207 \\
\hline Coefficient of determination, $\mathrm{R}^{2}$ & & \\
\hline
\end{tabular}

obarczony większym błędem niż model dla wtryskiwaczy piezoelektrycznych. Wskazują na to współczynniki determinacji $\mathrm{R}^{2}$ wynoszące odpowiednio 0,84 oraz 0,92 .

Pełną analizę wielkości opóźnienia wtrysku paliwa oraz procesu optymalizacji przedstawiono w tab. 5. Wynikają z niej znacznie krótsze czasy opóźnienia wypływu paliwa $\mathrm{z}$ wtryskiwaczy piezoelektrycznych niż elektromagnetycznych. Opóźnienie to jest około 3,5-krotnie większe dla wtryskiwaczy elektromagnetycznych niż piezoelektrycznych.
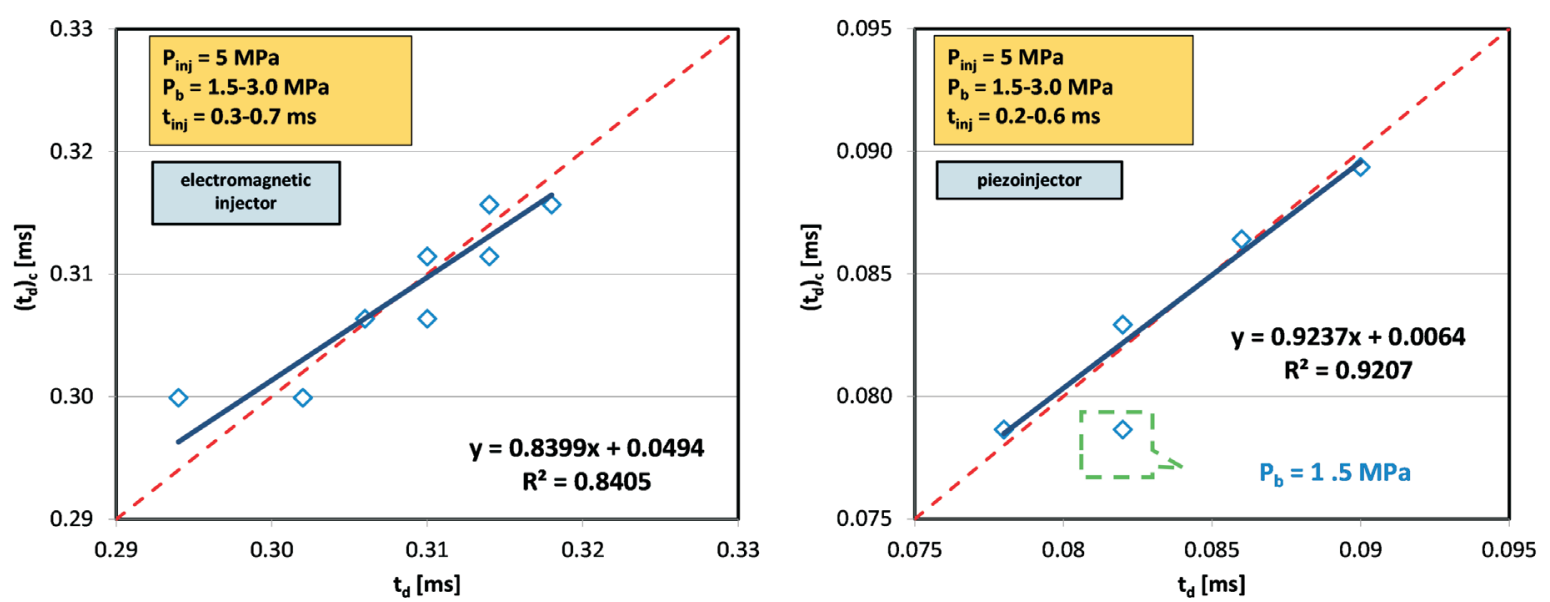

Fig. 12. The dependency of the fuel injection delay determined experimentally and analytically (conditions of the analysis are given in the figure) Rys. 12. Zależność określonego doświadczalnie i analitycznie opóźnienia wtrysku (warunki analizy podano na rysunku)

The result of the analysis presented in Figure 12 is a conclusion that the highest independence from the injection times exhibit piezoelectric injectors (a much greater number of identical points of delay in Figure 12b).

From the analysis shown in the Figure 12 it ensues that the model describing fuel injection delay for solenoid injectors at a pressure of $5 \mathrm{MPa}$ is encumbered with higher errors that the model for the piezoelectric injectors. It is indicated by the coefficient of determination $\mathrm{R}^{2}$ amounting, respectively, to 0.84 and 0.92 .

The full analysis of the parameters of fuel injection delay and the process of optimisation are presented in Table 5. From the analysis it is noticeable that the fuel flow delays are much shorter for piezoelectric injectors than for solenoid injectors. The delay time of fuel injection for a solenoid injector is about 3.5 times longer than for the piezoelectric injector.

\section{Summary}

1. An electric and optical analysis of the gasoline injection delay makes it possible to determine the parameters characterising the process. From the results of experimental studies were obtained different times of fuel injection delay relating to solenoid and piezoelectric injectors.

2. A delay in opening injectors can be described with the use of mathematical models in which the fuel pressure is

\section{Wnioski}

1. Analiza elektryczna i optyczna opóźnienia wtrysku benzyny umożliwia wyznaczenie wielkości charakteryzujących ten proces. $\mathrm{W}$ wyniku badań eksperymentalnych uzyskano odmienne czasy opóźnienia wtrysku paliwa dla wtryskiwaczy elektromagnetycznych i piezoelektrycznych.

2. Opóźnienie otwarcia wtryskiwaczy można opisać modelami matematycznymi, w których uwzględnia się ciśnienie paliwa. Analiza działania wtryskiwaczy elektromagnetycznych wskazuje na zmniejszenie czasu opóźnienia wypływu paliwa z wtryskiwacza wraz ze zwiększaniem ciśnienia paliwa (w zakresie 5-20 MPa). Opóźnienie wypływu paliwa $\mathrm{z}$ wtryskiwaczy piezoelektrycznych odnotowano jedynie w zakresie 5-10 MPa. Przy dalszym zwiększaniu ciśnienia paliwa opóźnienie jest stałe (niezależne od jego wartości).

3. Przy ciśnieniu $5 \mathrm{MPa}$ opóźnienie czasu działania wtryskiwaczy elektromagnetycznych jest proporcjonalne do przeciwciśnienia powietrza. Każde zwiększenie przeciwciśnienia powietrza $\Delta \mathrm{P}_{\mathrm{b}} \mathrm{o} 0,5 \mathrm{MPa}$ wywołuje zwiększenie czasu opóźnienia wypływu paliwa o $5,3 \mu$ s.

4. Przy małych wartościach ciśnienia paliwa (5 MPa) opóźnienie czasu działania wtryskiwaczy piezoelektrycznych jest również proporcjonalne do przeciwciśnienia powietrza. Każde zwiększenie przeciwciśnienia powietrza 
taken into account. The analysis of the operation of the solenoid injector indicates reduction of the fuel flow delay time from the injector with the increasing fuel pressure (within the range from 5 to $20 \mathrm{MPa}$ ). Fuel injection delay for piezoelectric injectors was reported only in the range of 5-10 MPa. For further increase of the fuel pressure, the delay was constant (independent of its value).

3. At a pressure of $5 \mathrm{MPa}$ the delay time for solenoid injectors is proportional to the backpressure of air. Any increase in the backpressure the air $\Delta \mathrm{P}_{\mathrm{b}}$ by $0.5 \mathrm{MPa}$ increases the time of fuel flow delay by $5.3 \mu \mathrm{s}$.

4. At low values of pressure $(5 \mathrm{MPa})$ the delay time for piezoelectric injectors is also proportional to the backpressure of air. Any increase in the backpressure the air $\mathrm{P}_{\mathrm{b}}$ by $0,5 \mathrm{MPa}$ increases the time of fuel flow delay by $3.5 \mu \mathrm{s}$.

5. The delay time of fuel injection for a solenoid injector for the same conditions of supply $\left(\mathrm{P}_{\text {inj }}, \mathrm{P}_{\mathrm{b}}\right)$ is about 3 times longer than for a piezoelectric injector. Both types of injectors tend to reduce delays when increasing the fuel flow pressure and to increase this delay with increasing medium backpressure (only at low differential pressure in the injector and $-\mathrm{P}_{\text {inj }}=55 \mathrm{MPa}$ ).

\section{Bibliography/Literatura}

[1] Achleitner, E., Bäcker, H., Funaioli, A. Direct injection systems for Otto engines. SAE Technical Paper 2007-01-1416, 2007, doi:10.4271/2007-01-1416.

[2] Cheng, Q., Zhang, Z., Xie, N. Power losses and dynamic response analysis of ultra-high speed solenoid injector within different driven strategies. Applied Thermal Engineering. 2015, 91, 611-621. doi:10.1016/j.applthermaleng.2015.08.053.

[3] Ferrari, A., Mittica, A., Spessa, E. Benefits of hydraulic layout over driving system in piezo-injectors and proposal of a new-concept $\mathrm{CR}$ injector with an integrated Minirail. Applied Energy, 2013, 103, 243-255.

[4] Gasoline systems high-pressure solenoid injector HDEV5. products.bosch-mobility-solutions.com (accessed 17.09.2016).

[5] Macian, V., Payri, R., Ruiz, S. et al. Experimental study of the relationship between injection rate shape and Diesel ignition using a novel piezo-actuated direct-acting injector. Applied Energy. 2014, 118, 100-113.

[6] Sim, J., Badra, J., Elwardany, A., Im, H. Spray modeling for outwardly-opening hollow-cone injector. SAE Technical Paper 2016-01-0844, 2016, doi:10.4271/2016-01-0844.

[7] Skowron, M., Pielecha, I. Ocena rozbieżności między sygnałami wymuszenia i rzeczywistej odpowiedzi wtryskiwaczy w układach bezpośredniego wtrysku paliw ciekłych. Combustion Engines. 2015, 3(162), 327-334.

[8] Skowron, M., Pielecha, I., Wisłocki, K. Transient states analysis of CI engine injectors with the use of optical methods. Publishing IOP Conf. Series: Materials Science and Engineering 2016, 148, 012085, doi:10.1088/1757-899X/148/1/012085.

[9] Tsai, W.-C, Yu, P.-C. Design of the electrical drive for the high-pressure GDI injector in a 500cc motorbike engine. International Journal of Engineering and Industries. 2011, 2(1), 70-83.

[10] Zhang, X., Palazzolo, A., Kweon, C., Thomas, E. et al. Direct fuel injector power drive system optimization. SAE Int. J. Engines. 2014, 7(3), doi:10.4271/2014-01-1442.
$\Delta \mathrm{P}_{\mathrm{b}}$ o $0,5 \mathrm{MPa}$ wywołuje zwięksszenie czasu opóźnienia wypływu paliwa o 3,5 $\mu \mathrm{s}$.

5. Opóźnienie wypływu paliwa z wtryskiwaczy elektromagnetycznych przy tych samych warunkach zasilania $\left(\mathrm{P}_{\text {inj }}, \mathrm{P}_{\mathrm{b}}\right)$ jest około 3-krotnie większe niż wtryskiwaczy piezoelektrycznych. Oba typy wtryskiwaczy wykazują tendencję do zmniejszenia opóźnienia wypływu paliwa podczas zwiększania ciśnienia zasilania oraz zwiększenia tego opóźnienia przy zwiększaniu przeciwciśnienia ośrodka (jedynie przy małej różnicy ciśnienia we wtryskiwaczu i ośrodku $-P_{\text {inj }}=55 \mathrm{MPa}$ ).

\section{Nomenclature/Oznaczenia}

ET Energizing Time/wymuszony czas trwania wtrysku paliwa $\mathrm{P}_{\mathrm{b}} \quad$ air backpressure/przeciwciśnienie ośrodka

$\mathrm{P}_{\mathrm{inj}} \quad$ fuel injection pressure/ciśnienie wtrysku paliwa

SIDI spark ignition direct injection/silniki o zaptonie iskrowym z bezpośrednim wtryskiem paliwa

MPI Multi Point Injection/wielopunktowy wtrysk paliwa

$\mathrm{t}_{\mathrm{d}} \quad$ total delay time of fuel injection/czas calkowitego opóźnienia wyplywu paliwa z wtryskiwacza

$\mathrm{t}_{\mathrm{e}} \quad$ electric delay time/czas elektrycznego opóźnienia wypływu paliwa

$\mathrm{t}_{\mathrm{h}} \quad$ hydraulic delay time/czas hydraulicznego opóźnienia wyplywu paliwa

$\mathrm{t}_{\mathrm{inj}} \quad$ injection time, $\mathrm{t}_{\mathrm{inj}}=\mathrm{ET} /$ czas wtrysku, przyjęto, że $t_{\text {inj }}$ jest równy ET

The research presented in this paper was performed within Statutory Activities no. 05/52/DSPB/0246-2016.

Ireneusz Pielecha, DSc., DEng. - professor in the Faculty of Machines and Transport at Poznan University of Technology.

Dr hab. inż. Ireneusz Pielecha, prof. PP-profesor na Wydziale Maszyn Roboczych i Transportu Politechniki Poznańskiej.

e-mail: ireneusz.pielecha@put.poznan.pl

Maciej Skowron, MEng. - postgraduate in the Faculty of Machines and Transport at Poznan University of Technology.

Mgr inż. Maciej Skowron - doktorant na Wydziale Maszyn Roboczych i Transportu Politechniki Poznańskiej.

e-mail:maciej.skowron@put.poznan.pl

Prof. Krzysztof Wisłocki, DSc., DEng. - Professor in the Faculty of Machines and Transport at Poznan University of Technology.

Prof. dr hab. inż. Krzysztof Wistocki - profesor na Wydziale Maszyn Roboczych i Transportu Politechniki Poznańskiej.

e-mail: krzysztof.wislocki@put.poznan.pl
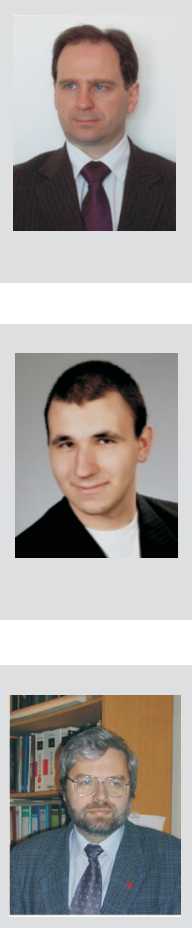